\title{
Distributed Collaborative Learning in Online LIS Education: A Curricular Analysis
}

\author{
Geoffrey Z. Liu \\ School of Library \& Information Science \\ San Jose State University, San Jose, CA, USA
}

Geoffrey.Liu@sjsu.edu

\begin{abstract}
This paper reports a case study of distributed collaborative learning in online library and information science (LIS) education using the method of quantitative curricular analysis. A total of 148 public course syllabi of Spring 2010 from a major LIS program in the western region of the United States were scrutinized to collect relevant data. The study finds that distributed collaborative learning is a prominent component of online LIS education, with discussion forums heavily used and group projects employed to a less degree. Part-time instructors are more likely to make forum posting mandatory, require weekly forum postings, and assign greater grading points to participation in forum discussion. Online forums are typically used for discussing assigned topics, book titles, or cases. More than 79\% of group project assignments are about developing a solution, and full-time instructors are more likely to utilize this instructional tactic.
\end{abstract}

Keywords: Collaborative learning, Online teaching, Library and information science (LIS) education.

\section{Introduction}

As web-based online teaching rapidly gains popularity in higher education, instructional approaches proven effective in traditional classroom teaching are transferred into online environments. One instructional approach that has been heavily promoted and widely practiced in both the traditional and online environments is collaborative learning. As collaborative learning takes hold in web-based online teaching, many studies on related issues have been published (An, Kim, \& Kim, 2008; Brindley, Blaschke, \& Walti, 2009; Janssen, Erkens, Kirschner, \& Kansellar, 2009; Prinsen, Volman, \& Terwel, 2007; Resta \& Laferrière, 2007; Volet, Summers, \& Thurman, 2009), and numerous research findings have been reported in support of its usefulness (Brack, Stauder, Doery, \& van Damme, 2007; Francescato, Mebane, Porcelli, Attanasio, \& Pulino, 2007; Han \& Hill, 2007; So \& Brush, 2008).

Graduate education of library and information science (LIS) is no exception. As more and more

Material published as part of this publication, either on-line or in print, is copyrighted by the Informing Science Institute. Permission to make digital or paper copy of part or all of these works for personal or classroom use is granted without fee provided that the copies are not made or distributed for profit or commercial advantage AND that copies 1) bear this notice in full and 2) give the full citation on the first page. It is permissible to abstract these works so long as credit is given. To copy in all other cases or to republish or to post on a server or to redistribute to lists requires specific permission and payment of a fee. Contact Publisher@InformingScience.org to request redistribution permission.
LIS programs are delivering courses over the Internet, having instructors teach online and students conduct collaborative learning activities in distributed web environments, researchers began to pay attention to pedagogical as well as technological issues related to online teaching (Harris, Kazmer, \& Mon, 2007; Pribesh, Dickinson, \& Bucker, 2006). Many 
studies have been published specifically on online LIS education, mostly from the perspectives of program/course design and student learning. Key issues examined in these studies include: (1) factors influencing student communication styles in problem-based learning (Yukawa, 2007); (2) online interaction (Burnett, Bonnici, Miksa, \& Kim, 2007; Du, Havard, \& Li, 2005; Stansberry, 2006) and learning experience (Kazmer, 2007); (3) gender difference (Marley, 2007), (4) learning styles and class participation (Simpson \& Du, 2004); (5) online LIS program development (Bunn, 2004; Mellon \& Kester, 2004 ; Montague \& Pluzhenskaia, 2007); (6) course design (Ausburn, 2004; Combes \& Anderson, 2006; Kazmer, 2006), and (7) virtual classroom (Kingma \& Keefe. 2006; Luo \& Kemp, 2008; Nicholson, 2005). However, there is no reported research of distributed collaborative learning in online LIS education on the curricular level, and little is known about instructors' implementation of this instructional approach in course design.

Students benefit from collaborative learning only if it is incorporated into course design and online teaching by instructors; therefore, it is equally important to investigate collaborative learning in online education from instructors' perspective as of from students' perspective, especially to look at instructors' actual implementation of this instructional approach.

This paper reports a case study of distributed collaborative learning in online LIS education. Essentially a curricular analysis, the study examines instructors' incorporation of collaborative learning components in their design of online courses, in a major LIS program in the United States. The study focuses on the extent of distributed collaborative learning being incorporated, forms and content/task nature of collaborative learning activities, and differences between core and elective courses as well as between part-time and full-time instructors.

The remaining content of this paper is organized as follows. First it establishes basic theoretical concepts by reviewing key relevant literature. After stating the research problem and questions, it documents the research method and reports both quantitative and qualitative findings. Finally, the paper concludes by discussing research findings and their implications for online LIS education.

\section{Theoretical Concepts}

Collaborative Learning is a complex and not clearly defined concept (Resta \& Laferrière, 2007). In their effort to identify an underlying theoretical framework for describing how collaborative learning occurs in the web environment, Han and Hill (2007) trace collaborative learning (as an educational theory) to its roots in social theories of learning and theories related to situated and shared cognition. By citing their 2006 work, they describe collaborative learning as "a social process of learning that takes place in the context of communities of inquiry”, and explain that "collaborative learning in this context is therefore not just an individual effort, but also a collective effort based on distributed intelligence” (p. 91).

Some writers have attempted to differentiate "collaborative" and "cooperative" learning, but there is neither universally adopted meaning of these terms nor agreement on precisely what their differences are. In spite of different wordings, the general sense seems to be that cooperative learning emphasizes division of labor among group members, while collaborative learning involves mutual engagement of participants in a coordinated effort to solve the problem together (Dillenbourg, 1999; Panitz, 1996; Roschelle \& Teasley, 1995). Further, cooperative learning tends to be associated with well-structured knowledge domains, but collaborative learning with ill-structured knowledge domains (Slavin, 1997). Collaborative learning requires small groups to confront complex, real-life situations in ill-structured problems (Smith \& Dirkx, 2007, p.26). Ultimately, collaborative learning and cooperative learning both involve instructional use of small groups in which students work together to maximize their own and each other's learning (Johnson \& Johnson, 1996). 
Collaborative learning also differs by learning tasks, which may be as simple as learning about a topical subject through collaborative literature research and shared discussion, or as sophisticated as developing solutions to an ill-defined problem. Having college students collaborate in pairs to learn a science text about the human circulatory system (Jeong \& Chi, 2007) is a good example of content-centered collaborative learning. In such cases, students are divided into groups to learn the content on a specific subject by participating in online communication - either asynchronous forum discussion or synchronous text/voice chat. As noted in Han \& Hill (2007), asynchronous discussion may be more effective for content-centered collaborative learning, and indeed it has been more preferable to both instructors and students alike.

In contrast to content-centered collaborative learning, problem-centered (and project-centered) collaborative learning necessitates frequent and much more intensive group interactions in real time, especially if the problem is ill defined or ill structured. McConnell (2005) observes that student groups engage in a considerable amount of synchronous communication in order to understand the problem, negotiate changes in their perception of the "problem", and revise solutions as their work progresses. Kapur \& Kinzer (2007) note that problem-centered interactional activities typically involve defining the problem, identifying relevant parameters, brainstorming solutions, evaluating and elaborating those suggestions, selecting solutions, and negotiating a final decision (p. 441). Where synchronous meetings of full group participation are not feasible, extreme difficulties arise in reaching consensus and validating group decisions (McConnell, 2005).

Online Collaborative Learning simply means that collaborative activities for learning take place in a computer-mediated environment. Resta and Laferrière (2007) categorize technological settings of collaborative learning as follows: technology-rich learning environments, networkenhanced learning environments, blended/hybrid learning environments (combining face-to-face and online interaction), and virtual learning environments. When one says "online collaborative learning” today, it is very unlikely to mean anything else but group learning activities in distributed environments - either within a web-based online teaching system (e.g., Blackboard or D2L), or using some Internet-based point-to-point text/audio/video communication software such as MSN Messenger and Skype, or both. To emphasize the distributed nature of technological environments and the fact that students participate in collaborative learning activities from different geographical locations in distance, the terms of "distributed collaboration", "distributed collaborative learning", and "distributed environments" are used in this paper.

The term “computer-supported collaborative learning” was used as early as in 1989, and soon the area was recognized as an important focus of research (Lipponen, Hakkarainen, \& Paavola, 2004). In the following years, various terminologies have been used in reference to group collaboration in educational context that involves information and communication technologies to different extents. For instance, "computer/technology mediated/supported group/collaborative learning”, “online group work”, “virtual team work”, and “distributed collaborative learning”, to list a few. In part, the rather chaotic use of terminologies is a result of changing information technologies employed to support group collaboration.

Just like collaborative learning in traditional classrooms, online collaborative learning can be content-centered or problem/project-centered. In problem/project-centered collaborative learning, students work in groups as virtual teams. They tend to carry out their collaborative activities synchronously in real-time meetings, but they may nevertheless choose to use an asynchronous communication platform, such as online discussion forum (Dewlyanti, Brand-Gruwel, Jochems, \& Broers, 2007; So, 2008) and wiki (Augar, Raitman, \& Zhou, 2011; Minocha \& Thomas, 2007; Trentin, 2008). Although content-centered collaborative learning could be synchronous, asynchronous discussion has been more preferable to both instructors and students alike (Han \& Hill, 2007), and it often takes the form of threaded discussion in online forums within the virtual learn- 
ing environment (Brindley, Blaschke, \& Walti, 2009; Cox \& Cox, 2008; Suthers, Vatrapu, Medina, Joseph, \& Dwyer, 2008; Wheeler, Yeomans, \& Wheeler, 2008).

When content-centered collaborative learning takes place in online forums, collaborative learning can take the form of threaded discussion within smaller groups or among the whole class (Brindley, Blaschke, \& Walti, 2009; Suthers et al., 2008). In this case, the effectiveness of collaborative learning for collective knowledge construction depends on the extent of forum postings being interrelated and interactive in content. As soon as students start making individual postings without relating to or commenting on issues raised by others, the collaborative element of online learning is lost. Therefore, one should not naively equate forum discussion with online collaborative learning, and should not assume that collaborative learning has taken place simply because students are busy posting chunks of text in the discussion forum.

\section{Research Objective}

The main objective of this study is to learn about current practices of collaborative learning in online LIS education. Specifically, the study aims to find out how collaborative learning as an instructional tactic is incorporated into course design and online teaching via the lens of a case study.

This study attempts to answer the following questions: (1) To what extent has distributed collaborative learning been incorporated into online LIS education? (2) What forms of distributed collaborative learning are frequently employed in the teaching of online LIS courses? Is one form preferred to another? What is the typical content nature or task type? (3) What differences exist between part-time and full-time instructors as well as between core and elective courses in terms of implementation of distributed collaborative learning?

\section{Research Method}

As a case study, this research examines collaborative learning in a major graduate program of LIS education in the western region of the United States by analyzing curricular design of online courses taught in the spring semester of 2010.

\section{Case Background}

The graduate LIS program (known as a "school of library and information science"), with a student population of about 3000 at the time of study, started offering its first online class in 1998 and had steadily increased online teaching of its curriculum in the following years. By the end of 2008, 229 classes in total were offered, of which $86.9 \%$ were taught completely online and $7 \%$ hybrid, with onsite classes accounting for only $6.1 \%$. The program finally went virtual in the spring of 2009, with all courses delivered online.

The program required students to complete three core courses before taking any elective ones and one course on research methods. To accommodate students' needs, multiple sections were offered for each of these required courses, often taught by different instructors. Although different sections of the same course needed to cover the same core content, instructors were allowed to customize content structure and use whatever instructional approaches and tactics as they pleased. On the other hand, an instructor might teach two sections of the same course in a given semester, for regular session and special session students respectively, and it was a common practice to combine regular and special session sections and teach as one online class.

Online teaching in this program was conducted via two major web-based systems. The Angel system was used for content distribution and management, class activity coordination, and assignment collection and grading. It provided technical functions common of instruction management 
systems, such as content pages, discussion forums, blogging, digital dropbox, and support for grading. The ElluminateLive! system was used for real-time class meeting, lecture recording (by some instructors), and student group activities. By completing an online reservation form, students could schedule online meetings for group interaction without involving the instructor.

\section{Data Gathering \& Analysis}

The primary source of research materials for this study is the school's official website, and the materials analyzed in this study were course syllabi (web pages) publicized by instructors. The school administration required all instructors to publicize their course syllabi (traditionally known as "green sheet" in this institution) on the school's website prior to the start of each semester. The course pages included overview of course content, class schedule, description of instructional approaches, assignments description, performance evaluation, and grading policy.

Each course syllabus (web page) publicized for the spring semester of 2010 was scrutinized for information related to collaborative learning, with particular attention to stipulation of class activities, assignments/project design, and grading policies. Relevant data were coded in terms of predefined variables characterizing course/instructor demographics and course-specific implementation of distributed collaborative learning. Multiple sections of the same course taught by the same instructor were treated as a single class and analyzed accordingly, since they were almost always combined into one online class, as explained earlier. The data were coded directly into a SPSS datasheet and analyzed for descriptive statistics as well as correlation patterns by cross tabulating and mean comparison. Statistical significances of correlation and mean differences were determined by chi-square test, Kendall's $\tau$ - $b$ test, and $t$-test when necessary and appropriate. All data gathering, coding, and analyses were done by the author.

\section{Results}

In total, 148 classes were examined for collaborative learning components, of which 25 (16.9\%) were taught by full-time instructors, and 38 (25.5\%) were core/required courses. The frequency distribution of classes by instructor status and class type is given in Table 1 . Forum discussion was required in $83.1 \%$ of all the courses and optional in $13.5 \%$ of them. Apparently, as a form of collaborative learning, forum discussion was very popular in the program. In contrast, only 35.8\% of classes required students to complete a group project.

Table 1 Distribution of Classes by Type and Instructor Status

\begin{tabular}{c|ccc|c}
\hline Instructor & Core/Required & Elective & Other & Total \\
\hline \multirow{2}{*}{ Full-Time } & 5 & 19 & 1 & 25 \\
& $20.0 \%$ & $76.0 \%$ & $4.0 \%$ & $16.9 \%$ \\
\multirow{3}{*}{ Part-Time } & 33 & 88 & 2 & 123 \\
& $26.8 \%$ & $71.5 \%$ & $1.6 \%$ & $83.1 \%$ \\
\hline Total & 38 & 107 & 3 & 148 \\
& $25.7 \%$ & $72.3 \%$ & $2.0 \%$ & \\
\hline
\end{tabular}

More in-depth analyses were conducted to investigate instructors' employment of discussion forums and group projects as two major approaches to collaborative learning online, with particular focus on differences between core and elective courses as well as between courses taught by fulltime and part-time instructors. The results are presented below in two subsections respectively. 


\section{Forum Discussion}

Significant difference was found between part-time and full-time instructors in likelihood to include forum posting as a mandatory learning task in online classes. Specifically, $90.8 \%$ of classes taught by part-time instructors (in comparison to $62.5 \%$ by full-time instructors) included forum posting as mandatory learning task $(\mathrm{N}=143$, Kendall's $\tau-b=0.304, p=0.011)$. Further, significant difference was also found between core and elective courses in this regard, with core courses more likely to make forum posting mandatory, as reflected in the percentages of classes in each case $\left(97.4 \%\right.$ vs. $\left.81.9 \%, \mathrm{~N}=143, \chi^{2}=5.546, \mathrm{p}=0.012\right)$.

To assess instructors' view of the importance of forum discussion in online teaching, grading points assigned to mandatory participation in forum discussion were analyzed. Of those classes that made forum posting mandatory, the amount of assigned points varied a great deal. On a normalized scale of one hundred points in total toward final grading, the amount of points assigned to mandatory forum posting ranged from 2 up to 75 , with a mean of $19.53(\mathrm{~N}=116, \mathrm{STD}=12.359)$. Mandatory forum posting accounted for 50 points or more in nearly $10 \%$ of these classes, and for 10 up to 34 points in other $50 \%$ of these classes. The specific distribution of classes by grading point ranges is given in Table 2 .

Table 2 Class Distribution by Grading Points for Forum Posting ( $f$ / \%)

\begin{tabular}{l|llllllll|l}
\hline Point Range & $<=5$ & $\mathbf{6 - 1 0}$ & $\mathbf{1 1 - 2 0}$ & $\mathbf{2 1 - 3 0}$ & $\mathbf{3 1 - 4 0}$ & $\mathbf{4 1 - 5 0}$ & $\mathbf{5 1 - 6 0}$ & $\mathbf{> 6 0}$ & Total \\
\hline Part-time & 4 & 16 & 41 & 24 & 6 & 3 & 1 & 8 & 103 \\
& $3.9 \%$ & $15.5 \%$ & $39.8 \%$ & $23.3 \%$ & $5.8 \%$ & $2.9 \%$ & $1.0 \%$ & $7.8 \%$ & $88.8 \%$ \\
Full-time & 0 & 3 & 9 & 1 & 0 & 0 & 0 & 0 & 13 \\
& 0.0 & $23.1 \%$ & $69.2 \%$ & $7.7 \%$ & 0.0 & 0.0 & 0.0 & 0.0 & $11.2 \%$ \\
\hline Core & 3 & 2 & 15 & 8 & 1 & 0 & 0 & 4 & 33 \\
& $9.1 \%$ & $6.1 \%$ & $45.5 \%$ & $24.2 \%$ & $3.0 \%$ & 0 & 0 & $12.1 \%$ & $28.4 \%$ \\
Elective & 1 & 17 & 35 & 17 & 5 & 3 & 1 & 4 & 83 \\
& $1.2 \%$ & $20.5 \%$ & $42.2 \%$ & $20.5 \%$ & $6.0 \%$ & $3.6 \%$ & $1.2 \%$ & $4.8 \%$ & $71.6 \%$ \\
\hline Total & 4 & 19 & 50 & 25 & 6 & 3 & 1 & 8 & 116 \\
& $3.5 \%$ & $16.4 \%$ & $43.1 \%$ & $21.6 \%$ & $5.2 \%$ & $2.6 \%$ & $0.9 \%$ & $6.9 \%$ & \\
\hline
\end{tabular}

It was found that part-time instructors awarded significantly more points to mandatory participation in forum discussion than full-time instructors did (18.51 vs. 8.04, $\mathrm{N}=136, t=3.639, p<0.001$ ). Nevertheless, no significant difference was found between core and elective courses in this aspect.

Frequencies of mandatory forum posting, as stipulated in course syllabi, were also analyzed, and the distribution of classes by posting frequencies is given in Table 3. Nearly half of classes with mandatory forum discussion required students to do on-going or weekly posting. Further analysis revealed that this trend was mainly determined by classes taught by part-time instructors. Of classes taught by part-time instructors with mandatory forum discussion, $54.6 \%$ were "weekly or ongoing”, while the corresponding percentage of classes by full-time instructors was $13.3 \%$. Of classes taught by full-time instructors, $46.7 \%$ did not specify required frequency of posting. The differences in relative percentages between full-time and part-time instructors noted above are statistically significant ( $\mathrm{N}=123$, Kendall's $\tau$ - $b=0.254, p=0.003$ ). No significant difference was found between core and elective courses. 
Table 3 Class Distribution of Frequency of Mandatory Posting $(f / \%)$

\begin{tabular}{l|llll|l}
\hline $\begin{array}{l}\text { Posting Fre- } \\
\text { quency }\end{array}$ & $\begin{array}{l}\text { Weekly or } \\
\text { ongoing }\end{array}$ & Biweekly & $\begin{array}{l}\text { Monthly or } \\
\text { irregular }\end{array}$ & Unspecified & Total \\
\hline Part-Time & 59 & 13 & 12 & 24 & 108 \\
& $54.6 \%$ & $12.0 \%$ & $11.1 \%$ & $22.2 \%$ & $87.8 \%$ \\
Full-time & 2 & 4 & 2 & 7 & 15 \\
& $13.3 \%$ & $26.7 \%$ & $13.3 \%$ & $46.7 \%$ & $12.2 \%$ \\
\hline Core & 18 & 7 & 2 & 31 & 37 \\
& $48.6 \%$ & $18.9 \%$ & $5.4 \%$ & $25.2 \%$ & $30.1 \%$ \\
Elective & 43 & 10 & 12 & 21 & 86 \\
& $50.0 \%$ & $11.6 \%$ & $14.0 \%$ & $24.4 \%$ & $69.9 \%$ \\
\hline Total & 61 & 17 & 14 & 31 & 123 \\
& $49.6 \%$ & $13.8 \%$ & $11.4 \%$ & $25.2 \%$ & \\
\hline
\end{tabular}

Given the popularity of forum discussion as a major tactic of incorporating collaborative learning into online LIS education, it is necessary to investigate the content nature of forum discussion in online classes. The frequency distribution of classes by content nature of mandatory forum discussion is given in Table 4.

Table 4 Class Distribution by Content Nature of Forum Discussion ( $f$ / \%)

\begin{tabular}{l|lllll|l}
\hline $\begin{array}{l}\text { Posting } \\
\text { Content }\end{array}$ & $\begin{array}{l}\text { Assigned } \\
\text { topic/book/ } \\
\text { case }\end{array}$ & $\begin{array}{l}\text { Lecture \& } \\
\text { readings }\end{array}$ & $\begin{array}{l}\text { Free } \\
\text { flowing }\end{array}$ & Other & Unspecified & Total \\
\hline Part-Time & 47 & 10 & 7 & 0 & 44 & 108 \\
& $43.5 \%$ & $9.3 \%$ & $6.5 \%$ & 0.0 & $40.7 \%$ & $87.8 \%$ \\
Full-time & 4 & 0 & 3 & 3 & 5 & 15 \\
& $26.7 \%$ & 0.0 & $20.0 \%$ & $20.0 \%$ & $33.3 \%$ & $12.2 \%$ \\
\hline Core & 8 & 2 & 3 & 1 & 23 & 37 \\
& $21.6 \%$ & $5.4 \%$ & $8.1 \%$ & $2.7 \%$ & $62.2 \%$ & $30.1 \%$ \\
Elective & 43 & 8 & 7 & 2 & 26 & 86 \\
& $50.0 \%$ & $9.3 \%$ & $8.1 \%$ & $2.3 \%$ & $30.2 \%$ & $69.9 \%$ \\
\hline Total & 51 & 10 & 10 & 3 & 49 & 123 \\
& $41.5 \%$ & $8.1 \%$ & $8.1 \%$ & $2.4 \%$ & $39.8 \%$ & \\
\hline
\end{tabular}

As expected, forum discussion was used mostly for content-centered collaborative learning. Two categories of forum discussion content -- discussing an "assigned topic/book title/case" and "Unspecified" - each accounted for about $40 \%$ of classes requiring mandatory forum posting. Although the general percentages of these two categories seemed approximately equal, further analysis revealed significant difference between core and elective courses ( $\mathrm{N}=123$, Kendall's $\tau$ - $b$ $=-0.221, p=0.012$ ). While core courses were more likely to have forum discussion content "unspecified”, elective courses were more likely to have students discuss assigned topic/book title/case in designated forums. 


\section{Group Project}

Compared to instructors' heavy use of discussion forums for content-centered collaborative learning online, group project was much less popular (among full-time and part-time instructors alike) as an instructional approach. In spite of its relatively low use in general, core courses were found more likely to include a group project assignment $\left(\mathrm{N}=138, X^{2}=10.847, p=0.001\right)$. Specifically, $60.5 \%$ of core courses included a group project assignment, while only $30 \%$ of elective courses did so.

In online teaching, group project may be of various types and used for different instructional purposes by design, not necessarily in direct correspondence to problem-centered collaborative learning. To gain a better understanding of the nature of group projects in online LIS education, analysis of group project task types was conducted. The frequency distribution of classes by group project task types is given in Table 5.

Table 5 Class Distribution by Group Project Task Types ( $f$ / \%)

\begin{tabular}{|c|c|c|c|c|c|c|}
\hline $\begin{array}{l}\text { Posting } \\
\text { Content }\end{array}$ & $\begin{array}{l}\text { Interview } \\
\text { peers }\end{array}$ & $\begin{array}{l}\text { Compile } \\
\text { resources }\end{array}$ & $\begin{array}{l}\text { As reading } \\
\text { club }\end{array}$ & $\begin{array}{l}\text { Identify } \\
\text { issues }\end{array}$ & $\begin{array}{l}\text { Design } \\
\text { solution }\end{array}$ & Total \\
\hline Part-Time & $\begin{array}{l}1 \\
2.4 \%\end{array}$ & $\begin{array}{l}5 \\
11.9 \%\end{array}$ & $\begin{array}{l}2 \\
4.8 \%\end{array}$ & $\begin{array}{l}3 \\
7.1 \%\end{array}$ & $\begin{array}{l}31 \\
73.8 \%\end{array}$ & $\begin{array}{l}42 \\
79.2 \%\end{array}$ \\
\hline Full-time & $\begin{array}{l}0 \\
0.0\end{array}$ & $\begin{array}{l}0 \\
0.0\end{array}$ & $\begin{array}{l}0 \\
0.0\end{array}$ & $\begin{array}{l}0 \\
0.0\end{array}$ & $\begin{array}{l}11 \\
100 \%\end{array}$ & $\begin{array}{l}11 \\
20.8 \%\end{array}$ \\
\hline Core & $\begin{array}{l}0 \\
0.0\end{array}$ & $\begin{array}{l}1 \\
4.4 \%\end{array}$ & $\begin{array}{l}0 \\
0.0\end{array}$ & $\begin{array}{l}1 \\
4.4 \%\end{array}$ & $\begin{array}{l}21 \\
91.3 \%\end{array}$ & $\begin{array}{l}23 \\
43.4 \%\end{array}$ \\
\hline Elective & $\begin{array}{l}1 \\
4.3 \%\end{array}$ & $\begin{array}{l}4 \\
13.3 \%\end{array}$ & $\begin{array}{l}2 \\
6.7 \%\end{array}$ & $\begin{array}{l}2 \\
6.7 \%\end{array}$ & $\begin{array}{l}21 \\
70.0 \%\end{array}$ & $\begin{array}{l}30 \\
56.6 \%\end{array}$ \\
\hline Total & $\begin{array}{l}1 \\
1.9 \%\end{array}$ & $\begin{array}{l}5 \\
9.4 \%\end{array}$ & $\begin{array}{l}2 \\
3.8 \%\end{array}$ & $\begin{array}{l}3 \\
5.7 \%\end{array}$ & $\begin{array}{l}42 \\
79.2 \%\end{array}$ & 53 \\
\hline
\end{tabular}

Of all those classes that required students to complete a group project, the task type of "designing/developing a solution product" accounted for about $80 \%$. This confirms that indeed group project was employed mostly for the purpose of implementing problem-centered collaborative learning. Furthermore, significant difference was found between full-time and part-time instructors in this aspect. Specifically, all group projects designed by full-time instructors, in contrast to $73.8 \%$ of those by part-time instructors, were of this task type ( $\mathrm{N}=53$, Kendall's $\tau$ - $b=0.251$, $p=0.002)$. Similar difference was found between core and elective courses as well ( $91.3 \%$ vs. $70 \%, \mathrm{~N}=53$, Kendall's $\tau-b=0.246, p=0.044)$. The correlation of differences between instructor status (part-time vs. full-time) and course type (core vs. elective) may be potentially explained by noting that full-time faculty were more likely to teach a core course, either by choice or by the administration's designation.

\section{Discussion}

In nutshell, the study finds that distributed collaborative learning is a prominent component of online LIS education, with discussion forums heavily used and group projects employed to a less degree. Significant differences are found between part-time and full-time instructors as well as between core and elective courses in instructional implementation of collaborative learning.

Only about 35\% of online courses incorporated group project assignments, and they are mostly for problem-centered collaborative learning. Core courses are more likely to include a group pro- 
ject assignment. Although group projects may be of a good variety of task types, in more than $79 \%$ of the cases, the group task is to complete a project or to develop a solution product, and full-time instructors are more likely to institute a solution development task as the group project.

The less frequent use of group project for collaborative learning probably has something to do with its relative unpopularity among students (King \& Behnke, 2005; Pfaff \& Huddleston, 2003) and instructors' tendency to play along. Besides typical issues in group work such as social loafing, personality dominance, and member conflict, students collaborating online need to deal with additional difficulties in coordinating group activities due to time zone difference, and in some cases, even cultural difference (Liu, 2010). In response to student reluctance and under the pressure of maintaining higher scores of student evaluation of teaching, some instructors may choose to avoid group project in designing their courses.

The heavy use of forum discussion for content-centered collaborative learning manifests not only in the large percentage of classes, but also in the significance of grading points allocated for participation in forum discussion. In about $10 \%$ of classes, mandatory participation in forum discussion accounts for more than half of the total points toward final grading. Online forum is used in more than $40 \%$ of online LIS classes for discussing assigned topics, book titles, or cases. However, to the same extent, the content of forum discussion may be unspecified at the time of publicizing the course syllabus, possibly to be decided later by the instructor as the semester unfolds.

To a great extent, the dominant use of forum discussion for content-centered collaborative learning and/or class interaction is determined by part-time instructors' choices of course design, given that $83.1 \%$ of classes in the program are taught by part-time instructors and that $90.8 \%$ of their classes require mandatory participation in forum discussion. They often require students to make weekly postings in online forums, and assign significantly more points to such activity than fulltime instructors do.

It is rather daring to speculate about what factors might have contributed to the differences between part-time and full-time instructors' online teaching practices. A few previous studies found that part-time instructors were less favorable than full-time instructors in professional attitudes and involvement in curricular/scholarly activities (Rifkin, 1998), time spent in various classroom practices (Schuetz, 2002), and availability to students outside of class (Hellman, 1998). In spite of all these differences, a more recent study (Landrum, 2009) examining both onsite and online classes found no significant difference in student ratings.

Although the findings from previous studies outlined above are not specific to online teaching, the identified differences between part-time and full-time instructors may help explain different choices they make in course design and online teaching practices.

\section{Conclusion}

Through a quantitative curricular analysis of publicized course syllabi in one graduate program, the study finds that distributed collaborative learning has been prominent in online teaching of LIS courses. Forum discussion is heavily used for content-centered collaborative learning, and group project is included only in a small percentage of online classes for problem-centered collaborative learning. Significant differences are found between part-time and full-time instructors in their implementation of the instructional approach of collaborative learning, and to a smaller extent between core and elective courses. Part-time instructors are much more likely to include forum discussion as a mandatory learning task, require weekly postings, and assign greater points to participation in online discussion. Group projects are more likely to be included in core courses for problem-centered collaborative learning, and most group projects are of the task type of "designing/developing a solution product”. 
These findings should be taken with awareness of inherent limitations of the study. A curricular analysis based on public web pages of course syllabi may not be sufficient to produce an accurate picture of distributed collaborative learning in online LIS education. Although the public syllabus serves as a contract between the course instructor and students, the teaching plan may change later into the semester. Additionally, it is possible that some instructional tactics of collaborative learning might have been employed in an online class but the instructor chose not to reveal in the public course syllabus.

The curricular analysis is useful for identifying general trends at the program level and revealing current practices of teaching in online LIS education. The findings from this study have increased our understanding of differences between part-time and full-time instructors, and have strong implication for policy development and program administration.

More research is needed to determine factors influencing instructors' choice of specific collaborative learning tactics in online courses, to understand what contributes to part-time instructors' heavy reliance on forum discussion, and to investigate if forum discussion is indeed used to facilitate collaborative learning (especially in groups) or simply as an asynchronous means of increasing student interaction in the whole class.

\section{Acknowledgement}

The author thanks anonymous reviewers for providing valuable comments and suggestions to improve the quality of this paper.

\section{References}

An, H., Kim, S., \& Kim, B. (2008). Teacher perspectives on online collaborative learning: Factors perceived as facilitating and impeding successful online group work. Contemporary Issues in Technology and Teacher Education, 8(1). Retrieved February 3, 2012, from http://www.citejournal.org/vol8/iss4/general/article1.cfm

Augar, N., Raitman, R., \& Zhou, W. (2011). Teaching and learning online with wikis. In R. Atkinsion, C. McBeath, D. Jonas-Dwyer, \& R. Phillips (Eds.), Beyond the comfort zone : Proceedings of the 21st ASCILITE Conference (pp. 95-104). Perth, WA: ASCILITE.

Ausburn, L. J. (2004). Course design elements most valued by adult learners in blended online education environments: An American perspective. Educational Media International, 41(4), 328-337.

Brack, C., Stauder, A., Doery, J. \& van Damme, M.P. (2007). Collaborative learning online: Integrating media in case-based learning for clinical biochemistry. In C. Montgomerie \& J. Seale (Eds.), Proceedings of the World Conference on Educational Multimedia, Hypermedia and Telecommunications (pp. 187-192). Chesapeake, VA: AACE.

Brindley, J., Blaschke, L. M., \& Walti, C. (2009). Creating effective collaborative learning groups in an online environment. The International Review of Research in Open and Distance Learning, 10(3). Retrieved February 3, 2012, from http://www.irrodl.org/index.php/irrodl/article/download/675/1313

Bunn, J. (2004, September). Student persistence in a LIS distance education program. Australian Academic \& Research Libraries, 35(3), 253-269.

Burnett, K., Bonnici, L. J., Miksa, S. D., \& Kim, J. (2007). Frequency, intensity and topicality in online learning: An exploration of the interaction dimensions that contribute to student satisfaction in online learning. Journal of Education for Library and Information Science, 48(1), 21-35.

Combes, B., \& Anderson, K. (2006). Supporting first year e-learners in courses for the information professions. Journal of Education for Library and Information Science, 47(4), 259-276.

Cox, B., \& Cox, B. (2008). Developing interpersonal and group dynamics through asynchronous threaded discussions: The use of discussion board in collaborative learning. Education, 128(4), 553-565. 
Dewlyanti, S., Brand-Gruwel, S., Jochems, W., \& Broers, N. J. (2007). Students' experiences with collaborative learning in asynchronous computer-supported collaborative learning environments. Computers in Human Behavior, 23(1), 496-514.

Dillenbourg, P. (Ed.). (1999). Collaborative learning: Cognitive and computational approaches. Oxford: Elsevier.

Du, J., Havard, B., \& Li, H. (2005). Dynamic online discussion: Task-oriented interaction for deep learning. Educational Media International, 42(3), 207-218.

Francescato, D., Mebane, M., Porcelli, R., Attanasio, C., \& Pulino, M. (2007). Developing professional skills and social capital through computer supported collaborative learning in university contexts. International Journal of Human-Computer Studies, 65(2), 140-152.

Han, S., \& Hill, J. (2007). Collaborate to learn, learn to collaborate: Examining the roles of context, community, and cognition in asynchronous discussion. Journal of Educational Computing Research, 36(1), 89-123.

Hellman, C. M. (1998). Faculty evaluation by students: A comparison between full-time and adjunct faculty. Journal of Applied Research in the Community College, 6, 45-50.

Harris, L., Kazmer, M.M., \& Mon, L. (2007). From the guest editors: A new decade of online LIS education. Journal of Education for Library and Information Science, 48(1), 1-4.

Janssen, J., Erkens, G., Kirschner, P.A., \& Kansellar, G. (2009). Influence of group member familiarity on online collaborative learning. Computers in Human Behavior, 25(1), 161-170. DOI: http://dx.doi.org/10.1016/j.chb.2008.08.010

Jeong, H., \& Chi, M. (2007). Knowledge convergence and collaborative learning. Instructional Science, 35(4), 287-315.

Johnson, D. W., \& Johnson, R. T. (1996). Cooperation and the use of technology. In D. Jonassen (Ed.), Handbook of research for educational communications and technology (pp. 785-812). London: MacMillan.

Kapur, M., \& Kinzer, C. (2007). Examining the effect of problem type in a synchronous computersupported collaborative learning (CSCL) environment. Educational Technology Research \& Development, 55(5), 439-459.

Kazmer, M. M. (2006). Creation and loss of sociotechnical capital among information professionals educated online. Library and Information Science Research, 28, 172-191.

Kazmer, M.M. (2007). How do student experiences differ in online LIS programs with and without a residency? The Library Quarterly, 77(4), 359-383.

King, P. E., \& Behnke, R.R. (2005). Problems associated with evaluating student performance in groups. College Teaching, 53(2), 57-61.

Kingma, B., \& Keefe, S. (2006). An analysis of the virtual classroom: Does size matter? Do residencies make a difference? Should you hire that instructional designer? Journal of the Education for Library and Information Science, 47(2), 127-143.

Landrum, E. (2009), Are there instructional differences between full-time and part-time faculty? College Teaching, 57(1), 23-26.

Lipponen, L., Hakkarainen, K., \& Paavola, S. (2004). Practices and orientations of CSCL. In J. W. Strijbos, P. A. Kirschner, \& R. L. Martens (Eds.), What we know about CSCL in higher education (pp. 31-51). Dordrecht: Kluwer.

Liu, G. Z. (2010). Spontaneous group decision making in distributed collaborative learning: Toward a new research direction. MERLOT Journal of Online Learning and Teaching, 6(1), 279-296.

Luo, L., \& Kemp, J. (2008). Second Life: Exploring the immersive instructional venue for library and information science education. Journal of Education for Library and Information Science, 49(3), 47-166. 
Marley, J. L. (2007). Gender differences and distance education: Major research findings and implications for LIS education. Journal of Education for Library and Information Science, 48(1), 13-20.

McConnell, D. (2005). Examining the dynamics of networked e-learning groups and communities. Studies in Higher Education, 30(1), 25-42.

Mellon, C. A., \& Kester, D. D. (2004). Online library education programs: Implications for rural students. Journal of Education for Library and Information Science, 45(3), 210-220.

Minocha, S., \& Thomas, P. G. (2007). Collaborative learning in a wiki environment: Experiences from a software engineering course. New Review of Hypermedia and Multimedia, 13(2), 187-209.

Montague, R. A., \& Pluzhenskaia, M. (2007). Web-based information science education (WISE): Collaboration to explore and expand quality in LIS online education. Journal of Education for Library and Information Science, 48(1), 36-51.

Nicholson, S. (2005). A framework for technology selection in a web-based distance education environment: Supporting community-building through richer interaction opportunities. Journal of Education for Library and Information Science, 46(3), 217-233.

Panitz, T. (1996). A definition of collaborative versus cooperative learning. Deliberations [Online]. Retrieved from http://www.londonmet.ac.uk/deliberations/collaborative-learning/panitz-paper.cfm.

Pfaff, E., \& Huddleston, P. (2003). Does it matter if I hate teamwork? What impacts student attitudes toward teamwork. Journal of Marketing Education, 25(1), 37-45.

Pribesh, S., Dickinson, G. K., \& Bucher, K. T. (2006). A comparison of online and face-to-face cohorts in a school library media specialist graduate program: A preliminary study. Journal of Education for Library and Information Science, 47(4), 303-323.

Prinsen, F.R., Volman, M.K.K., \& Terwel, J. (2007). Gender-related differences in computer-mediated communication and computer-supported collaborative learning. Journal of Computer Assisted Learning, 23(5), 393-409.

Resta, P., \& Laferrière, T. (2007). Technology in support of collaborative learning. Educational Psychology Review, 19(1), 65-83.

Rifkin, T. (1988). Differences between the professional attitudes of full- and part-time faculty. Paper presented at the American Association of Community Colleges Convention (Miami, FL, April 27, 1998).

Roschelle, J., \& Teasley, S. (1995). The construction of shared knowledge in collaborative problem solving. In C. E. O’Malley (Ed.), Computer supported collaborative learning (pp. 69-197). Berlin Heidelberg New York: Springer.

Schuetz, P. (2002). Instructional practices of part-time and full-time faculty. New Directions for Community Colleges, 118, 39-46.

Simpson, C., \& Du, Y. (2004). Effects of learning styles and class participation on students' enjoyment level in distributed learning environments. Journal of Education for Library and Information Science, 45(2), 123-136.

Slavin, R. E. (1997). Educational psychology: Theory and practice (5th ed.). Needham Heights, MA: Allyn \& Bacon.

Smith, R., \& Dirkx, J. (2007). Using consensus groups in online learning. New Directions for Adult \& Continuing Education, 113, 25-35.

So, H.-J. (2008). When groups decide to use asynchronous online discussions: Collaborative learning and social presence under a voluntary participation structure. Journal of Computer Assisted Learning, 25(2), 143-160.

So, H.-J., \& Brush, T. A. (2008). Student perceptions of collaborative learning, social presence and satisfaction in a blended learning environment: Relationships and critical factors. Computers \& Education, 51(1), 318-336. 
Stansberry, S. (2006). Effective assessment of online discourse in LIS courses. Journal of Education for Library and Information Science, 47(1), 27-37.

Suthers, D. D., Vatrapu, R., Medina, R., Joseph, S., \& Dwyer, N. (2008). Beyond threaded discussion: Representational guidance in asynchronous collaborative learning environments. Computers \& Education, 50(4), 1103-1127.

Trentin, G. (2008). Using a wiki to evaluate individual contribution to a collaborative learning project. Journal of Computer Assisted Learning, 25(1), 43-55.

Volet, S., Summers, M., \& Thurman, J. (2009). High-level co-regulation in collaborative learning: How does it emerge and how is it sustained? Learning and Instruction, 19(2), 128-143. DOI: http://dx.doi.org/10.1016/j.learninstruc.2008.03.001

Wheeler, S., Yeomans, P., \& Wheeler, D. (2008). The good, the bad and the wiki: Evaluating studentgenerated content for collaborative learning. British Journal of Educational Technology, 39(6), 987995.

Yukawa, J. (2007). Factors influencing online communication style in LIS problem-based learning. Journal of Education for Library and Information Science, 48(1), 52-63.

\section{Biography}

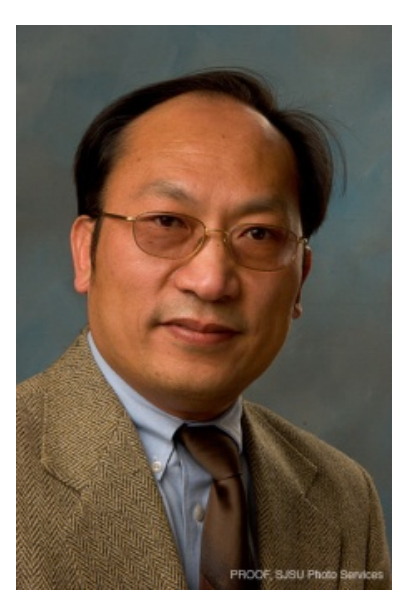

Dr. Geoffrey Z. Liu is Associate Professor in the School of Library and Information Science at San Jose State University, California. He holds a Ph.D. in information science from University of Hawaii at Manoa and an MA in library science from Wuhan University, China. His research interests include automatic indexing and information retrieval, virtual community and computer-mediated communication, and group decision making in online collaborative learning. He has published research in influential international journals in these areas. 